\title{
How stress mediators can cumulatively contribute to Alzheimer's disease An allostatic load approach
}

\author{
Tatiane Martins Matos ${ }^{1}$, Juliana Nery De Souza-Talarico²
}

\begin{abstract}
Allostatic load is defined as the frequent activation of the neuroendocrine, immunological, metabolic and cardiovascular systems, which makes individuals more susceptible to stress-related health problems. According to this model, physiological dysregulations start to emerge decades before diseases manifest. Consequently, stress research has shifted its attention to anticipating the degree of this dysregulation to better understand the impact of stress hormones and other biomarkers on disease progression. In view of the growing number of studies that demonstrate the influence of modifiable risk factors on cognitive decline, in addition to the effects of chronic stress mediators, the objective of the present review was to present an overview of the development of cognitive changes based on studies on stress and its mediators.
\end{abstract}

Key words: stress, Alzheimer's disease, allostatic load, cognitive decline, memory.

COMO OS MEDIADORES DE ESTRESSE PODEM CONTRIBUIR CUMULATIVAMENTE PARA A DOENÇA DE ALZHEIMER: UMA ABORDAGEM DE CARGA ALOSTÁTICA

RESUMO. A carga alostática é definida como a ativação frequente dos sistemas neuroendócrino, imunológico, metabólico e cardiovascular, o que torna os indivíduos mais suscetíveis a problemas de saúde relacionados ao estresse. Segundo este modelo, as desregulações fisiológicas começam a surgir décadas antes das doenças se manifestarem. Consequentemente, a pesquisa de estresse tem desviado sua atenção para antecipar o grau de desregulação para entender melhor 0 impacto dos hormônios do estresse e outros biomarcadores na progressão da doença. Tendo em vista 0 crescente número de estudos que demonstram a influência de fatores de risco modificáveis no declínio cognitivo além dos efeitos dos mediadores crônicos do estresse, o objetivo da presente revisão foi apresentar uma visão geral do desenvolvimento de alterações cognitivas a partir de estudos sobre o estresse e seus mediadores.

Palavras-chave: estresse, doença de Alzheimer, carga alostática, declínio cognitivo, memória.

\begin{abstract}
A lthough various factors are associated with cognitive decline during aging, it is unclear which factors trigger the neurodegenerative process in cases of dementia. Chronic exposure to stress throughout the lifespan has been the focus of many studies because of the similarities between the biological mechanisms involved in chronic stress and the pathophysiology of Alzheimer's disease (AD), one of the leading causes of dementia
\end{abstract}

worldwide. There is consistent evidence showing that cortisol, the main stress mediator, is associated with both cognitive decline and AD. However, it remains unclear whether the altered cortisol is the cause or consequence of neurodegeneration. Beta-amyloid $(\mathrm{A} \beta$ ) protein deposition, neuroinflammation, hyperphosphorylation of tau protein, changes in glucose metabolism and insulin signaling are some of the effects of primary mediators of

This study was conducted at the School of Nursing, Department of Medical-Surgical Nursing, University of São Paulo, São Paulo, SP, Brazil.

${ }^{1}$ Nurse, Master of Science from the School of Nursing, University of São Paulo (EE-USP), SP, Brazil. 2Professor at the Department of Medical-Surgical Nursing School of Nursing, University of São Paulo (EE-USP), SP, Brazil. PhD In the Area of Neurobiology of Stress and Cognition.

Juliana Nery De Souza-Talarico. Av. Dr. Enéas De Carvalho Aguiar, 419 - Depto. Enc - 05403-000 São Paulo SP - Brazil - E-Mail: Junery@usp.br

Disclosure: The authors report no conflicts of interest.

Received, September 03, 2018. Accepted in final form, December 17, 2018.

(cc) BY 
stress that cumulatively can cause decreases in the synaptic network and neuroplasticity, hippocampal and cortical atrophy, and consequently, cognitive decline. This "wear and tear" of chronic stress known as allostatic load is related to the prolonged and sustained exposure to the primary stress mediators that progressively damage brain structures associated with cognitive functions, increasing the risk of disease. This review will explain the similarities between the mechanisms that trigger $\mathrm{AD}$ and the effects of stress mediators in the brain to support the hypothesis that, through the allostatic load process, chronic stress during lifespan may seed the vulnerability for developing cognitive impairment later in life.

\section{ALZHEIMER'S DISEASE: NEUROPATHOLOGY AND ASSOCIATED FACTORS}

Alzheimer's disease is the most common form of dementia and is responsible for approximately $60 \%$ to $80 \%$ of the cases of the disease worldwide. ${ }^{1}$ The syndrome, which affects approximately 35 million people worldwide, is characterized by gradual and progressive cognitive impairment, including memory decline, impaired reasoning and judgment and slow processing speed allied with executive dysfunction, behavioral and functional decline. ${ }^{2,3} \mathrm{AD}$ leads to the death of nerve cells, gradually causing atrophy in different brain regions which, over time, affects almost all of its functions. The exact neuropathological mechanism by which this neurodegenerative process unfolds is still being studied. It has been established that cognitive and behavioral AD symptoms are correlated with the accumulation of amyloid plaques in the extracellular environment and with intracellular neurofibrillary tangles, which destroy synapses essential to learning, memory, planning and decision making. ${ }^{4-6}$ Amyloid plaque formation is due to the accumulation of $A \beta$ peptide, which, in turn, is caused by a change in the amyloid precursor protein (APP) cleavage process. ${ }^{7}$ APP is a transmembrane protein which normally undergoes either neuroprotective or amyloidogenic cleavage. Through the action of the $\beta$-secretase enzyme, APP is transformed into $A \beta$ peptide. In early-onset familial $A D$, accumulation of $A \beta$ peptide is related to genetic insults in APP and mutations in presenilin genes (PSEN). After age, the presence of the E4 allele of the gene that codes apolipoprotein E (APOE-\&4) represents the largest risk factor for $A \beta$ accumulation in late-onset $A D$. In addition, epigenetic changes and environmental risks also contribute to the accumulation of toxic species of $A \beta$ in late-onset $\mathrm{AD}{ }^{4}$

When hyperphosphorylation of tau protein forms neurofibrillary tangles within the cells, cell morphology is altered (microtubule disassembly), disrupting axoplasmic flow and inducing neuronal dysfunction and neurodegeneration. ${ }^{7,8}$ One of the hypotheses for this hyperphosphorylation is that, when combined with neuroinflammation and oxidative stress, $A \beta$ accumulation causes dysregulation in calcium channels and hyperactivation of kinases, leading to tau hyperphosphorylation., ${ }^{4,9,10}$

Various studies with animals and humans have shown that neuroinflammation, mediated by microglial activation, plays an important role in the amyloidogenic process (for a review, see Hommet et al., 2014). ${ }^{11}$ Although microglial activation is beneficial in $A D$ because it facilitates the elimination of $\mathrm{A} \beta$ peptide, ${ }^{12-15}$ it may also damage brain tissue due to the release of proinflammatory mediators, such as IL-1 $\beta$, IL-6, and TNF $\alpha .{ }^{11}$ Neuroinflammation, in turn, leads to oxidative stress, cell damage and death in structures essential for cognitive abilities and, consequently, to cognitive decline. ${ }^{11}$ However, the exact factor that contributes to the activation of this neuroinflammation process is still unclear. Although genetic elements such as APOE allele 4 are significant $\mathrm{AD}$ risk factors, other factors represent risk conditions for the disease. Similarities between the effects of chronic stress and the neuropathological mechanisms involved in the development of $\mathrm{AD}$ have reinforced the hypothesis that chronic stress is an important risk factor for cognitive decline during the aging process and for the conversion of mild cognitive impairment $(\mathrm{MCI})$ to $\mathrm{AD}$.

The present article reports evidence that supports the hypothesis that chronic stress may be one of these "other factors" involved in the $\mathrm{AD}$ neurodegenerative process.

\section{ACUTE AND CHRONIC STRESS: PRIMARY MEDIATORS, SIDE EFFECTS, AND ILLNESS}

Since its introduction in medical sciences in the 1930s, the concept of stress has evolved, especially because of advances in the field of neuroscience. Stress is a natural and adaptive reaction to challenging or threatening situations and is, therefore, beneficial and necessary for the body to continue functioning. In the short term, various biological, cognitive and behavioral modifications take place so that individuals can adapt to stressful stimuli (acute stress response). ${ }^{16}$ However, stress responses maintained for prolonged or repetitive periods (chronic stress response) can affect the operation of the organism's adaptive biological systems, causing illness. ${ }^{16}$

Stress response starts with the perception that something threatening or challenging is occurring, i.e., when someone is exposed to a stressful event. Stress- 
ors can be classified into two types: real or absolute, i.e., those that are undeniably life-threatening (for example: natural catastrophes, or situations of violence, such as a kidnapping or assault) and relative stressors, where the perception of threat or challenge essentially depends on interpretation (for example: new or unpredictable situations, with little control or social judgment). Unlike real stressors, not everyone responds the same way or with the same intensity to relative stressors. New or unpredictable stressors may represent a challenge or threat to some people, whereas for others, stress occurs in situations over which they have little control or in which they are being judged by others. Whether real or relative, exposure to stressors activates the sympathoadrenal system (SAM), which stimulates catecholamine (adrenaline and noradrenaline) secretion by the adrenal medulla and results in cardiovascular changes (increased heart rate and vasoconstriction), metabolic changes (increased oxygen supply and glucose bioavailability), immunological changes (increased anti-inflammatory factors and coagulation) and cognitive changes (activation of attention and memory for decision-making). The hypothalamic-pituitary-adrenal (HPA) axis is then activated, which stimulates the neurons of the paraventricular nucleus of the hypothalamus to secrete corticotropin-releasing hormone ( $\mathrm{CRH}$ ). $\mathrm{CRH}$ acts on the anterior pituitary to release adrenocorticotropic hormones (ACTH), responsible for stimulating the cortex of the adrenal gland to synthesize and release glucocorticoids (corticosterone in animals and cortisol in humans). ${ }^{16-18}$ These glucocorticoids then cross the blood-brain barrier, binding to specific receptors - mineralocorticoids (MR) and glucocorticoids (GR) located in brain structures intrinsically related to memory and attention. The interaction of glucocorticoids with these receptors exerts negative feedback, acting on the hypothalamus, which reduces $C R H$ synthesis and $A C T H$ secretion in the anterior pituitary and regulates plasma cortisol concentration, restoring it to concentrations prior to exposure to the stressor. ${ }^{18-20}$

Activation of the SAM and HPA axes modifies the operational parameters of stress response target systems (cardiovascular, immunological, neuroendocrine and metabolic systems), so that, in the short term, energy is mobilized in the form of glucose to prepare the organism for a fight-or-flight response. ${ }^{21}$ These adaptive modifications, called the allostatic response or allostase, occur through the action of primary mediators (glucocorticoids, dehydroepiandrosterone [DHEA], catecholamines, glucose, and pro- and anti-inflammatory cytokines [IL- 6 and TNF- $\alpha$ ]) that act on the mitochon- drial DNA of target system cells to enhance the ability of the mitochondria to produce energy and, consequently, boost cellular energetic capacity for the fight-or-flight response..$^{21,22}$ Glucocorticoids also modulate the mitochondrial function, increasing membrane potential, $\mathrm{Ca}^{2+}$ signaling, and resistance to apoptosis. ${ }^{23}$

Overall, in acute situations, these primary mediators (i.e. cortisol, glucose, IL-6, DHEA and catecholamines) seek to ensure the organism's best possible adaptation to the demands imposed by stressors. However, in chronic situations, the sustained action of these primary mediators through repeated stress responses can dysregulate the target systems in a process called allostatic load characterized by secondary outcomes. ${ }^{24,25}$ The prolonged action of glucocorticoids and glucose on mitochondrial DNA increases oxidative reactions, causing cellular dysfunction, telomere shortening, epigenetic dysregulation with altered gene expression of mitochondrial DNA, and cellular aging. ${ }^{26,27}$ Over time, these combined changes dysregulate the stress response target systems, whose operational parameters are modified to pathophysiological levels (above or below normal limits), as an adaptive mechanism to offset the cumulative effects of the primary mediators. As a result, the different stress response target systems manifest secondary effects such as increased metabolic mediators (insulin, glucose, total cholesterol, high-density lipoprotein, triglycerides, visceral fat deposition), cardiovascular mediators (blood pressure) and immune mediators (fibrinogen and $\mathrm{C}$-reactive protein), in addition to reduced protective mediators, such as high-density lipoproteins (HDL cholesterol) and DHEA hormones. ${ }^{22,24,28}$ These mediators reach subclinical concentrations, ${ }^{24}$ i.e., levels above or below the expected average, indicating a load on the allostatic system (allostatic load), which is a risk condition for disease. If maintained, these effects can progressively accumulate and overload the allostatic system, triggering tertiary effects that are manifested through the emergence of cardiovascular and immunological diseases or mental and cognitive disorders. 22,24,25,28

In summary, the effects of the stress response unfold in a structured process through a sequential chain of biological events, which starts with the adaptation of the systems to the demands of stressors, and, if prolonged, leads to multi-systemic dysregulation and culminates in disease (allostasis, allostatic state, allostatic load and allostatic overload). This process can be positively or negatively modulated by genetic, behavioral and environmental factors, biological reserves, lifestyle, and previous experiences that shape individuals' coping and adaptation ability, i.e. resilience to stress. ${ }^{29}$ 


\section{CHRONIC STRESS AND ITS EFFECTS ON THE CENTRAL NERVOUS SYSTEM}

The main consequence of chronic exposure to stress response mediators in the central nervous system is cellular and structural damage, primarily in the hypothalamus, cortex and hippocampus. ${ }^{30-32}$ In these areas, a repeated and sustained increase in the concentration of glucocorticoids triggers neurotoxic effects mediated by neuroinflammation and hyperglycemic states. The accumulation of these effects increases the production of reactive specimens and induces oxidative stress. Consequently, the mitochondrial respiratory chain decreases in activity, which curbs potential action of the membrane, impairs cellular ability to produce energy, and sensitizes neuronal apoptosis. ${ }^{23,33}$ In addition, neuroinflammation observed in the hippocampus of rats after exposure to chronic stress (IL-1 Beta, IL-6, TNF-alpha) also appears to result in mental health disorders and cognitive impairment because of increased proinflammatory cytokines, microglial activation and recruitment of monocytes in the caudal hippocampus, associated with temporary working memory loss and neurogenesis impairment. The rat's immune response was a result of sympathetic activation during exposure to stressors. ${ }^{34}$

Although there is no direct evidence, these cellular alterations may explain the association noted in other studies between higher glucocorticoid concentration and decreased neurogenesis, dendritic arborization, and neural cell adhesion molecules (NCAM), in addition to reduced synaptic capacity and atrophy in various brain regions, including the hippocampus and cortex. $^{23,24,30,31,35,36}$

Another effect of chronically high concentrations of glucocorticoids is hyperglycemia and decreased insulin signaling in the brain. ${ }^{37-39}$ Prolonged hyperglycemia alters mitochondrial morphology ${ }^{37,38}$ causing effects such as excessive fragmentation, oxidative stress and impaired mitochondrial DNA integrity, ${ }^{22,40,41}$ facilitating neuronal apoptosis. ${ }^{42}$ Moreover, the accumulation of glucose in the blood activates immune cells, such as macrophages, which stimulate the secretion of proinflammatory cytokines (IL- 1 and TNF- $\alpha$ ). These cytokines, linked to their receptors, promote the activation of a group of kinases, which act on insulin receptors. In these receptors, densely manifested in the hypothalamus, entorhinal cortex and hippocampus, ${ }^{43}$ these kinases act on insulin receptor substrates, altering metabolism and insulin signaling in the brain, which promotes hyperinsulinemia and insulin resistance. ${ }^{44,45}$ Decreased insulin in the neurons impairs neuroplasticity, learning, and memory formation. ${ }^{46-48}$
From a functional point of view, one of the main effects of the accumulation of these cellular and structural damage in the hypothalamus, prefrontal cortex, and hippocampus is the progressive dysregulation of the HPA axis. Whether by direct action of the glucocorticoids or through its effect on glucose metabolism and insulin signaling, cell damage caused by these structures alters the binding sites of the MR and GR receptors in the hippocampus and prefrontal cortex, besides affecting inhibition of the HPA axis ${ }^{49}$ and, consequently, the negative feedback process. This maintains glucocorticoid secretion high, which produces a vicious cycle, further impairing HPA axis regulation. Another major side effect produced by the neurotoxic action of glucocorticoids at high concentrations in the hippocampus is poorer learning and memory performance..$^{50}$ The saturation of GR receptors caused by hypercortisolism reduces longterm potentiation (LTP) - an important neurobiological substrate - and impairs memory formation. Studies have shown that excess circulating glucocorticoid due to chronic stress leads to increased activation of GR receptors. This inhibits LTP in the hippocampus ${ }^{51-53}$ and reduces the brain-derived neurotrophic factor (BDNF) level, which negatively affects memory performance. ${ }^{54,55}$

Whether these cognitive effects are temporary or permanent depends on the period of exposure to the stressor event. The harmful effects of stress are intensified during windows of vulnerability, when there is sustained action of its mediators during periods of insufficient functional biological reserves, i.e., during periods of brain development (in childhood) or during its degeneration (aging). ${ }^{56}$ The harmful effects of chronic stress on memory may not be permanent in adulthood, i.e., once the stressor has ceased, cortisol concentrations return to baseline levels and memory performance improves. However, the cumulative damage from exposure to stress response mediators over the lifespan produces structural changes in the brain that increase the risk of developing cognitive disorders during aging, such as $\mathrm{AD}$.

\section{CUMULATIVE EFFECTS OF CHRONIC STRESS AND ALZHEIMER'S DISEASE}

Prolonged stress conditions and the absence of adaptive coping strategies cause the accumulation of structural and functional changes in the hippocampus and prefrontal cortex, induced by the sustained action of primary mediators of stress response in the central nervous system. This constitutes a risk condition for developing cognitive impairment and dementia. The hypothesis that chronic stress may be a risk factor for 
Table 1. Effects of the primary mediators of chronic stress and their similarity with the mechanisms that trigger Alzheimer's disease.

\begin{tabular}{|c|c|c|c|}
\hline Primary mediators & Mechanisms & Effects & Relationship with \\
\hline Cortisol and glucose & $\begin{array}{l}\uparrow \text { Cortisol induces } \\
\text { hyperglycemia and insulin } \\
\text { resistance }\end{array}$ & $\begin{array}{l}\text { - Increased } A \beta \text { peptide formation } \\
\text { - Neuroinflammation, oxidative stress } \\
\text { and cellular damage } \\
\text { - Hyperphosphorylation of tau protein } \\
\text { - Decreased neuroplasticity } \\
\text { - Hippocampal atrophy and memory loss }\end{array}$ & $\begin{array}{l}\text { - In individuals with } \mathrm{MCl} \text { or } \mathrm{AD} \text {, there is } \\
\text { a change in the HPA axis and cortisol } \\
\text { concentration } \\
\text { - } \mathrm{DM} 2 \text { is associated with higher risk of } \mathrm{AD}\end{array}$ \\
\hline DHEA-S & $\begin{array}{l}\downarrow D H E A-S \text { is associated with } \\
\text { immunological dysfunction }\end{array}$ & $\begin{array}{l}\text { - Lower brain protection against } A \beta \\
\text { toxicity } \\
\text { - Lower antioxidant defenses and } \\
\text { vascular protection } \\
\text { - Increased atherogenesis } \\
\text { - Memory decline }\end{array}$ & - DHEA-S decreased in AD patients \\
\hline $\begin{array}{l}\text { Proinflammatory } \\
\text { cytokines }\end{array}$ & 个IL-6 and IL-1 & $\begin{array}{l}\text { - Change in APP metabolism, facilitating } \\
\text { the amyloidogenic pathway } \\
\text { - Increased A } \beta \text { deposition } \\
\text { - Demyelination } \\
\text { - Synaptic dysregulation and } \\
\text { neurodegeneration }\end{array}$ & - IL-6 increased in AD patients \\
\hline
\end{tabular}

Aß: beta-amyloid; MCl: mild cognitive impairment; AD: Alzheimer's disease; HPA: hypothalamic-pituitary-adrenal; DM2: type 2 diabetes mellitus; DHEA-S: Dehydroepiandrosterone sulfate; IL-6: interleukin 6; IL-1: interleukin 1; APP: amyloid precursor protein.

$\mathrm{AD}$ is primarily based on the similarities between the effects of its primary mediators and the mechanisms that trigger $\mathrm{AD}$ (Table 1). As previously explained, chronic exposure to stress mediators induces neuroinflammation, hyperglycemic states associated with changes in glucose metabolism and insulin signaling, $A \beta$ accumulation, and hyperphosphorylation of tau protein (Table 1). Mediated by oxidative stress, these combined changes affect neuronal functioning, altering synaptic transmission and neuroplasticity, and lead to hippocampal atrophy, causing impaired cognitive performance, especially in learning and memory (Table 1).

Animal studies have shown that high concentrations of glucocorticoids (comparable with those observed in stress situations) are associated with increased $A \beta$ peptide formation due to higher APP and $\beta$-secretase enzyme concentrations, increased phosphorylation of tau protein in the hippocampus and prefrontal cortex and, consequently, the formation of neurofibrillary tangles. ${ }^{57,58}$ In these studies, poorer performance in learning and memory tasks ${ }^{59-61}$ was also observed in animals with higher corticosterone concentrations. Peptide accumulation and the hyperphosphorylation of tau protein, induced by prolonged exposure to high corticosterone concentrations, were prevented by administering mifepristone, a glucocorticoid receptor antagonist, which strengthens the causal relationship between glucocorticoids and the neuropathology of $\mathrm{AD} .{ }^{62}$ Treatment with

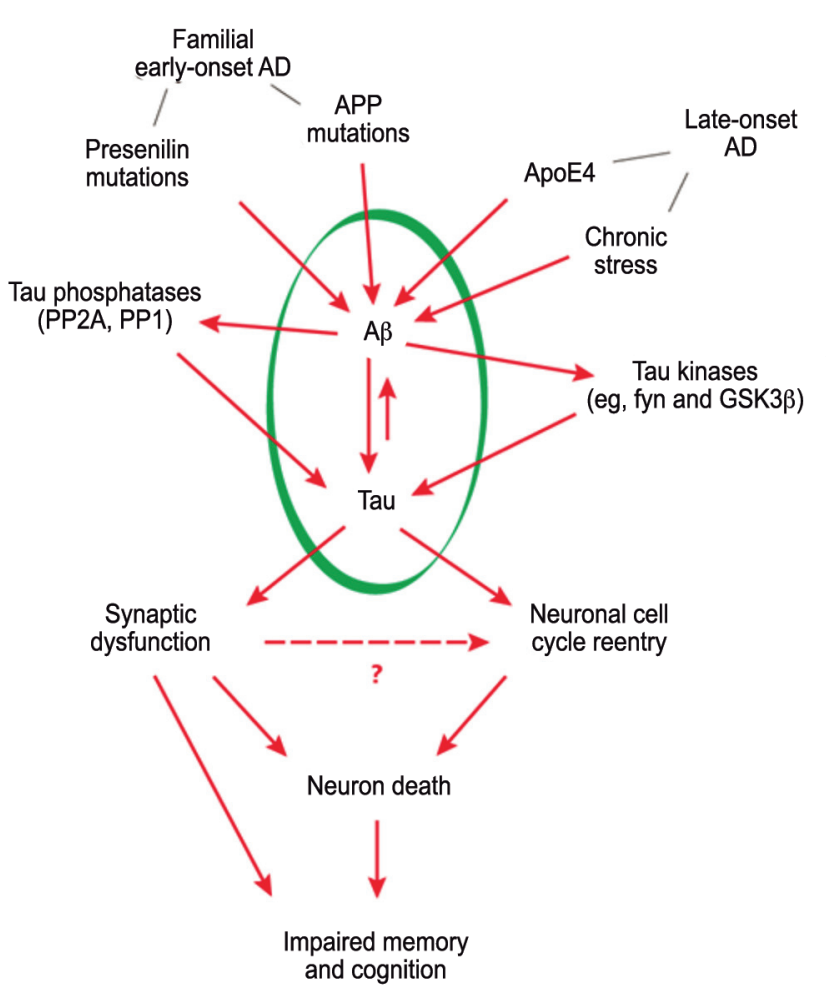

Figure 1. Factors associated with Amyloid-beta peptide accumulation. Chronic stress may constitute another factor that contributes to the accumulation of toxic amyloid beta in late-onset Alzheimer's disease. Betaamyloid peptide accumulation promotes the formation of pathological tau tangles that lead to synaptic dysfunction and memory-supporting neuron death, impairing cognitive performance. 
mifepristone prevented APP cleavage by $\beta$-secretase, blocked $A \beta$ production and, consequently, reversed cognitive deficits. ${ }^{62}$

In humans, considering a continuous health-disease process, changes in cortisol concentration associated with poor cognitive performance have been observed in healthy individuals or with memory complaints in patients with $\mathrm{MCI}$ and $\mathrm{AD} .^{63-78}$ Older adults without cognitive impairment who had been exposed to intense occupational stress during adulthood had low episodic memory performance. ${ }^{65,66} \mathrm{~A}$ longitudinal study demonstrated that older adults with high cortisol concentrations over a period of six years had worse declarative memory performance and $14 \%$ less hippocampal volume than those with lower cortisol concentrations. ${ }^{64}$ Individuals with memory complaints - an important prodrome and risk factor for dementia - have higher cortisol concentrations than those not affected by this problem. ${ }^{67}$ Similarly, workers with high occupational stress levels at 40 years of age have a higher risk of developing $\mathrm{MCI}$ and $\mathrm{AD} 20$ years later. ${ }^{68}$ Various studies have noted higher cortisol concentrations in $\mathrm{MCI}$ and $\mathrm{AD}$ patients than in cognitively healthy older adults. ${ }^{69-76}$ In older adults with $\mathrm{AD}^{77}$ or $\mathrm{MCI},{ }^{78}$ the higher the cortisol concentration, the worse the cognitive performance. Furthermore, the conversion of older adults with $\mathrm{MCI}$ to $\mathrm{AD}^{79}$ or from mild $\mathrm{AD}$ to moderate $\mathrm{AD}^{77}$ is also associated with increased cortisol concentration. As a whole, the relationship between higher cortisol and poorer cognitive performance since adulthood in individuals suffering from memory deficits ${ }^{63}$ - ranging from individuals with $\mathrm{MCI}$ to those who already have $\mathrm{AD}$ - strongly suggests that cortisol not only contributes to the evolution of the disease, but is also involved in the pathophysiological mechanisms that cause it. ${ }^{76,77,79}$

A large body of evidence has shown that the cumulative effects of chronic stress on $\mathrm{AD}$ pathology is based on the concentration of glucocorticoids (corticosterone or cortisol). However, other primary mediators of chronic stress, such as glucose, DHEA-S and proinflammatory cytokines, are also associated with AD (Table 1).

Changes in brain glucose metabolism contribute to cell degeneration and appear to be associated with the onset and progression of AD. ${ }^{42}$ High glucose concentrations, mediated by hypercortisolism, insulin resistance and altered glucose metabolism in the brain, are associated with $A \beta$ accumulation and increased phosphorylation of tau protein..$^{80-85}$ Various epidemiological studies have demonstrated an independent association between $\mathrm{AD}$ and type 2 diabetes mellitus (DM2). A meta-analysis found that DM2 increases the risk of developing AD by
$39 \%$ regardless of the presence of cardiovascular comorbidities. ${ }^{86}$ Although there is no conclusive explanation for this association, one hypothesis suggests that it is mediated by moderate hypercortisolism usually present in the early stages of $\mathrm{AD} .{ }^{87}$ The circadian rhythm of cortisol secretion is one of the main determinants of glycemia in humans, and high concentrations of cortisol over a long period of time may be diabetogenic due to adrenal hyperresponsiveness to ACTH ${ }^{87}$ Hypercortisolism increases the risk of a pre-diabetic condition and DM2 in older adults with mild $\mathrm{AD}$, decades before dementia manifests. ${ }^{87}$ See Table 1.

The reduced concentration of DHEA/DHEA-S inherent to aging is associated with dysfunction and activation of the immune system, ${ }^{88}$ increased oxidative stress ${ }^{89}$ and atherogenesis. ${ }^{90}$ DHEA is an androgen produced by the adrenal glands that acts as an antagonist against the negative effects of increased cortisol by suppressing inflammatory cytokines, improving lipid metabolism, decreasing insulin resistance, and reducing brain damage caused by oxidative stress. ${ }^{91}$ In a cohort study, patients with AD had lower plasma DHEA-S and DHEA levels than control volunteers. ${ }^{91-93}$ There is evidence that DHEA protects hippocampal cells from the toxicity produced by the accumulation of $A \beta$ protein. ${ }^{94}$ Decreased circulating DHEA may also contribute to the vascular pathology observed in $\mathrm{AD}$, since DHEA has antioxidant properties. ${ }^{91}$ By contrast, higher endogenous DHEA-S levels were independently associated with better executive function, concentration, and working memory in healthy older adults. ${ }^{123}$ Therefore, lower DHEA and DHEA-S concentrations undermine their neuroprotective effect, and represent a risk factor for the cumulative effects of chronic stress and progression or development of $\mathrm{AD}$ (Table 1). ${ }^{91,94}$

Regarding proinflammatory cytokines, some authors claim that $\mathrm{AD}$ is fundamentally an immunologically driven process, since IL- 6 and IL- 1 are associated with altered APP metabolism. ${ }^{95}$ One study used the immunohistochemistry technique on brain tissue and showed that in the early stages of $\mathrm{AD}$, amyloid plaques are colocalized with acute-phase proteins and proinflammatory cytokines. ${ }^{96}$ Interleukin IL-1 and IL-6 have been associated with neuronal damage because of increased $A \beta$ deposition, ${ }^{97}$ demyelination and neurodegeneration. ${ }^{98}$ IL-6 levels were high in the AD population compared to healthy older adults and inversely correlated with Mini-Mental State Examination scores. ${ }^{99}$ Reducing the concentration of proinflammatory cytokines could have beneficial effects on AD symptomatology. ${ }^{100}$ A metaanalysis demonstrated that, regardless of age, older 
adults with $\mathrm{AD}$ display higher concentrations of IL- $6^{99}$ (Table 1).

The similarities between chronic stress and AD are not limited to the effects of their primary mediators. Secondary effects of chronic stress, represented by allostatic load biomarkers, are also associated with dementia, reinforcing the hypothesis that prolonged stress constitutes a risk factor for $\mathrm{AD}$.

One of the main allostatic load biomarkers that represents the secondary outcomes of the sustained action of primary stress mediators is altered concentration of the HDL (high-density lipoprotein) fraction of cholesterol. Higher HDL concentrations are positively correlated with cognitive function. ${ }^{101,102}$ Some authors have reported that low HDL concentrations are associated with cognitive impairment, regardless of the presence of atherosclerotic disease. ${ }^{103}$ Consistent with this finding, a study conducted in middle-aged adults (55 to 61 years old) identified an association between low HDL concentrations ( $<40 \mathrm{mg} / \mathrm{dL}$ ) and memory decline over the course of five years, even when controlling for variables known to influence cognitive performance. ${ }^{104}$ However, individuals with higher HDL concentrations had less cognitive impairment and improved memory performance. ${ }^{105} \mathrm{~A}$ meta-analysis showed a positive association between HDL and memory performance during aging. ${ }^{102}$ The association between low HDL concentrations and cognitive impairment is mainly because of its role in regulating the metabolism and deposition of $\mathrm{A} \beta$ protein, ${ }^{106}$ its influence on atherosclerotic disease, and its anti-inflammatory properties. ${ }^{107-109}$ Low apoA-I concentration (the main protein component of plasma $\mathrm{HDL}$ ) is the main predictor of cognitive decline over the course of two years in $\mathrm{MCI}$ patients. ${ }^{110}$ In $\mathrm{AD}$ patients, the lower the concentration of HDL and apoA-I, the greater the severity of the disease $\mathrm{e}^{111}$ and the risk of developing it. ${ }^{112,113}$

Another allostatic load biomarker, also present in $\mathrm{AD}$, is a higher body mass index (BMI). ${ }^{114-116}$ Obesity has been associated with elevated cardiovascular and cortisol responses to acute stress. ${ }^{124} \mathrm{~A}$ meta-analysis showed an association between obesity and increased risk of $\mathrm{AD} .{ }^{114}$ Approximately $2 \%$ of cases of $\mathrm{AD}$ worldwide are potentially related to obesity in middle age. ${ }^{114}$ A $10 \%$ reduction in the prevalence of obesity could prevent more than 66,000 cases of $\mathrm{AD}$ worldwide. ${ }^{114}$ Another study noted a U-shaped association, i.e., the two ends of BMI (low or high) were statistically and significantly associated with cognitive performance and $A D$ risk. ${ }^{116,124}$ Some studies have suggested that being overweight or obese in middle age is a risk for later devel- opment of cognitive decline and dementia. ${ }^{116,125}$ One biological pathway hypothesized to link obesity to cognitive impairment is through leptin, a hormone mainly produced by adipocytes which suppresses appetite and regulates energy expenditure. In rodents, leptin receptor disruption is associated with impaired long-term potentiation, synaptic plasticity and spatial learning, while higher levels of leptin in the hippocampus result in decreased neurodegeneration. ${ }^{126,127}$ Moreover, higher plasma leptin is strongly associated with low $A \beta$ levels in the mouse brain, supporting a protective role for the hormone in $\mathrm{AD}$ onset. ${ }^{128}$ Similarly, higher levels of leptin in humans are associated with increased hippocampal and whole brain volume and reduced incidence of AD. ${ }^{129}$ Conversely, decreased leptin levels in $\mathrm{AD}$ patients with inappropriately low weight suggests a malfunction at the hypothalamic level. ${ }^{130}$ With regard to cognition, one study showed leptin to have a modest protective effect against cognitive decline. ${ }^{131}$ Interestingly, individuals with greater adiposity and/or higher plasma leptin would be more stress-responsive. ${ }^{132}$

The immunological side effects of chronic stress also share similarities with AD. One meta-analysis found an association between levels of $\mathrm{C}$-reactive protein (CRP) - a marker of systemic inflammation (acute phase) and heightened risk of developing AD. ${ }^{117}$ Another study noted higher concentrations of high-sensitivity CRP in $\mathrm{AD}$ patients than in healthy individuals..$^{99}$ Similarly, high CRP levels are associated with low memory, visuospatial impairment and low global cognitive performance. ${ }^{133,134}$

Finally, the allostatic load index - the estimated risk of illness due to chronic stress, which includes concentrations of primary mediators and secondary effects of stress - is related to poorer cognitive performance. ${ }^{118-120}$ Individuals with higher allostatic load index scores showed greater cognitive decline and mortality risk than those with lower scores. ${ }^{121,122}$ Furthermore, high allostatic load was associated with low total brain volume and white-matter volume and low general cognitive ability, processing speed, and knowledge in older adults. ${ }^{120}$

Taken together, these studies clearly demonstrate that both cognitive decline and $\mathrm{AD}$ are intrinsically linked to primary mediators of stress and its secondary effects manifested by allostatic load biomarkers. Given that chronic stress may be manageable, allostatic load signs allied with subjective cognitive decline may help implement preventive strategies early during adulthood to reduce the prevalence of dementia later in life. As a multisystemic effect, allostatic load may be controlled through diverse pathways including diet interventions whereby the consumption of nutrients exerting antioxi- 
dant effects may reduce the oxidative stress produced by sustained action of stress mediators. ${ }^{135-137}$

\section{CONCLUSION}

Different elements produce a nonlinear and multisystemic association between the effects of the primary and secondary mediators of chronic stress and the mechanisms that trigger AD. Although acute stress is a natural and necessary response to maintain the human organism, chronic exposure to its biological mediators can cumulatively impair brain structures essential to cognitive functioning, thus representing a risk factor for cerebral aging and vulnerability to cognitive decline. The early identification in adulthood of individuals who report constant psychological stress and have altered allostatic load mediators constitutes a promising target of interventions to reduce the prevalence of dementia and contribute to successful cerebral aging. In this context, diet and nutritional status interventions can play an important preventive role.

Authors contributions. All authors contributed significantly to, and approved, the content of this manuscript.

Acknowledgements. The current study was supported by the Coordenação de Aperfeiçoamento de Pessoal de Nível Superior (CAPES).

\section{REFERENCES}

1. Alzheimer's Association. 2013 Alzheimer's disease facts and figures. Alzheimer's \& dementia. 2013;9(2):208-45.

2. Dubois B, Feldman HH, Jacova C, Cummings JL, DeKosky ST, Barberger-Gateau P, et al. Revising the definition of Alzheimer's disease:a new lexicon. Lancet Neurol. 2010;9(11):1118-27.

3. Prince M, Bryce R, Albanese E, Wimo A, Ribeiro W, Ferri CP. The global prevalence of dementia:a systematic review and metaanalysis. Alzheimers Dement. 2013;9(1):63-75.

4. Bloom GS. Amyloid- $\beta$ and tau:the trigger and bullet in Alzheimer disease pathogenesis. JAMA Neurol. 2014;71(4):505-8.

5. Gómez-Isla T, Price JL, McKeel Jr DW, Morris JC, Growdon JH, Hyman BT. Profound loss of layer II entorhinal cortex neurons occurs in very mild Alzheimer's disease. J Neurosci. 1996;16(14):4491-500.

6. Schuff N, Woerner N, Boreta L, Kornfield T, Shaw LM, Trojanowski JQ, et al. The Alzheimer's Disease Neuroimaging Initiative. MRI of hippocampal volume loss in early Alzheimer's disease in relation to ApoE genotype and biomarkers. Brain. 2009;132(4):1067-77.

7. Selkoe DJ. The molecular pathology of Alzheimer's disease. Neuron. 1991;6(4):487-498.

8. Busciglio J, Lorenzo A, Yeh J, Yankner BA. $\beta$-Amyloid fibrils induce tau phosphorylation and loss of microtubule binding. Neuron. 1995;14(4): 879-88.

9. Block ML, Zecca L, Hong JS. Microglia-mediated neurotoxicity: uncovering the molecular mechanisms. Nat Rev Neurosci. 2007;8(1):57-69.

10. Li Y, Liu L, Barger SW, Griffin WST. Interleukin-1 mediates pathological effects of microglia on tau phosphorylation and on synaptophysin synthesis in cortical neurons through a p38-MAPK pathway. J Neurosci. 2003;23(5):1605-11.

11. Hommet C, Mondon K, Camus V, Ribeiro MJ, Beaufils E, Arlicot N, et al. Neuroinflammation and $\beta$ amyloid deposition in Alzheimer's disease:in vivo quantification with molecular imaging. Dement Geriatr Cogn Disord. 2014;37(1-2):1-18.

12. Meda L, Baron P, Scarlato G. Glial activation in Alzheimer's disease: the role of Abeta and its associated proteins. Neurobiol Aging. 2001;22(6): 885-93.

13. Morgan D, Gordon MN, Tan J, Wilcock D, Rojiani AM. Dynamic complexity of the microglial activation response in transgenic models of amyloid deposition: implications for Alzheimer therapeutics. J Neuropathol Exp Neurol. 2005;64(9):743-53.

14. Tuppo EE, Arias HR. The role of inflammation in Alzheimer's disease. Int J Biochem Cell Biol. 2005;37(2):289-305.

15. Hickman SE, Allison EK, El Khoury J. Microglial dysfunction and defective beta-amyloid clearance pathways in aging Alzheimer's disease mice. J Neurosci. 2008;28(33):8354-60.

16. Shonkoff JP, Boyce WT, McEwen BS. Neuroscience, molecular biology, and the childhood roots of health disparities:building a new framework for health promotion and disease prevention. JAMA. 2009;301(21): 2252-9.

17. Sapolsky RM, Romero LM, Munck AU. How do glucocorticoids influence stress responses? Integrating permissive, suppressive, stimulatory, and preparative actions. Endocr Rev. 2000;21(1):55-89.

18. Lupien SJ, Maheu F, Tu M, Fiocco A, Schramek TE. The effects of stress and stress hormones on human cognition:Implications for the Field of brain and cognition. Brain and Cognition. 2007;65(3):209-37.

19. Joels M, de Kloet ER. Effects of glucocorticoids and norepinephrine on the excitability in the hippocampus. Science. 1989;245(4925):1502-5.

20. de Kloet ER, Oitzl MS, Joels M. Stress and cognition:are corticosteroids good or bad guys? Trends in Neurosci. 1999;22(10):422-6.

21. Sterling P, Eyer J. Allostasis: Stress, cognition and health. Philadelphia (Pennsyvania): John Wiley \& Sons. 1988; Allostasis a new paradigma to explain arousal pathology. p.629-40.

22. Picard M, Juster RP, McEwen BS. Mitochondrial allostatic load puts the "gluc" back in glucocorticoids. Nat Rev Endocr. 2014;10(5):1-8.

23. Du J, Wang Y, Hunter R, Wei Y, Blumenthal R, Falke C, et al. Dynamic regulation of mitochondrial function by glucocorticoids. Proc Natl Acad Sci USA. 2009;106(9):3543-8.

24. Juster RP. McEwen BS, Lupien SJ. Allostatic load biomarkers of chronic stress and impact on health and cognition. Neurosci Biobehav Rev. 2010;35(1):2-16.

25. McEwen BS. Interacting mediators of allostasis and allostatic load: towards an understanding of resilience in aging. Metabolism. 2003;52: 10-6.

26. Sapolsky RM. The physiological relevance of glucocorticoid endangerment of the hippocampus. Ann N Y Acad Sci. 1994;746(1):294-304.

27. Lin MT, Beal MF. Mitochondrial dysfunction and oxidative stress in neurodegenerative diseases. Nature. 2006;443(7113):787-95.

28. McEwen BS. Proctetive and damaging effects of stress mediators. N Engl J Med. 1998;338(3):171-9.

29. McEwen BS. Stress, adaptation, and disease:Allostasis and allostatic load. Ann N Y Acad Sci. 1998;840(1):33-44.

30. Madrigal JL, Olivenza R, Moro MA, Lizasoain I, Lorenzo P, Rodrigo J, et al. Glutathione depletion, lipid peroxidation and mitochondrial dysfunction are induced by chronic stress in rat brain. Neuropsychopharmacology. 2001;24(4):420-9.

31. Gong $Y$, Chai $Y$, Ding JH, Sun XL, Hu G. Chronic mild stress damages mitochondrial ultrastructure and function in mouse brain. Neurosci Lett. 2011;488(1):76-80.

32. Rezin GT, Cardoso MR, Gonçalves CL, Scaini G, Fraga DB, Riegel $\mathrm{RE}$, et al. Inhibition of mitochondrial respiratory chain in brain of rats subjected to an experimental model of depression. Neurochem Int. 2008;53(6-8):395-400.

33. Tang VM, Young AH, Tan H, Beasley C, Wang JF. Glucocorticoids increase protein carbonylation and mitochondrial dysfunction. Horm Metab Res. 2013;45(10):709-15.

34. McKim DB, Niraula A, Tarr AJ, Wohleb ES, Sheridan JF, Godbout, JP. Neuroinflammatory dynamics underlie memory impairments after repeated social defeat. J Neurosci. 2016;36(9):2590-604.

35. Sandi C. Stress, cognitive impairment and cell adhesion molecules. Nature Rev Neurosci. 2004;5(12):917. 
36. Landfield P, Baskin RK, Pitler TA. Brain-aging correlates:retardation by hormonal-pharmacological treatments. Science. 1981;214(4520):581-3.

37. Shalev I, Entringer S, Wadhwa PD, Wolkowitz OM, Puterman E, Lin J, et al. Stress and telomere biology:a lifespan perspective. Psychoneuroendocrinology. 2013;38(9):1835-42.

38. Testa R, Olivieri F, Sirolla C, Spazzafumo L, Rippo MR, Marra M, et al. Leukocyte telomere length is associated with complications of type 2 diabetes mellitus. Diabetic Med. 2011;28(11):1388-94.

39. Stein LJ, Dorsa DM, Baskin DG, Figlewicz DP, Porte JR, Woods SC. Reduced effect of experimental peripheral hyperinsulinemia to elevate cerebrospinal fluid insulin concentrations of obese Zucker rats. Endocrinology. 1987;121(5):1611-5

40. Medikayala S, Piteo B, Zhao X, Edwards JG. Chronically elevated glucose compromises myocardial mitochondrial DNA integrity by alteration of mitochondrial topoisomerase function. Am J Physiol Cell. 2011; 300(2):C338-48.

41. Suzuki S, Hinokio Y, Komatu K, Ohtomo M, Onoda M, Hirai S, et al. Oxidative damage to mitochondrial DNA and its relationship to diabetic complications. Diabetes Res Clin Pract. 1999;45(2-3):161-8.

42. Lee YJ, Jeong SY, Karbowski M, Smith CL, Youle RJ. Roles of the mammalian mitochondrial fission and fusion mediators Fis1, Drp1, and Opa1 in apoptosis. Mol Biol Cell. 2004;15(11):5001-11.

43. Marks JL, King MG, Baskin DG. Localization of insulin and type 1 IGF receptors in rat brain by in vitro autoradiography and in situ hybridization. Adv Exp Med Biol. 1991;293:459-70.

44. Rehman K, Akash MS. Mechanisms of inflammatory responses and development of insulin resistance:how are they interlinked? J Biomed Sci. 2016;23(1):87

45. Roman-Pintos LM, Villegas-Rivera G, Rodriguez-Carrizalez AD, MirandaDiaz AG, Cardona-Muñoz EG. Diabetic Polyneuropathy in Type 2 Diabetes Mellitus: Inflammation, Oxidative Stress, and Mitochondrial Function. J Diabetes Res. 2016. Article ID 3425617

46. Cardona-Gómez GP, Mendez P, DonCarlos LL, Azcoitia I, GarciaSegura LM. Interactions of estrogens and insulin-like growth factorin the brain:implications for neuroprotection. Brain Res Rev. 2001; 37(1-3):320-34

47. Dudek H, Datta SR, Franke TF, Birnbaum MJ, Yao R, Cooper GM, et al. Regulation of neuronal survival by the serine-threonine protein kinase Akt. Science. 1997;275(5300):661-5

48. Martin ED, Sanchez-Perez A, Trejo JL, Martin-Aldana JA, Cano Jaimez $\mathrm{M}$, Pons S, et al. IRS-2 Deficiency impairs NMDA receptor-dependent long-term potentiation. Cereb Cortex. 2012;22(8):1717-27.

49. Sapolsky R, Krey L, McEwen BS. The adrenocortical stress response in the aged male rat:impairment of recovery from stress. Exp Gerontol. 1983;18(1):55-64

50. Lupien SJ, de Leon M, De Santi S, Convit A, Tarshish C, Nair NPV, et al. Cortisol levels during human aging predict hippocampal atrophy and memory deficits. Nature Neurosci. 1998;1(1):69.

51. Artola A, Von Frijtag JC, Fermont PC, Gispen WH, Schrama LH, Kamal $A$, et al. Long区lasting modulation of the induction of LTD and LTP in rat hippocampal CA1 by behavioural stress and environmental enrichment. Eur J Neurosci. 2006;23(1):261-72.

52. Kim JJ, Diamond DM. The stressed hippocampus, synaptic plasticity and lost memories. Nature Rev Neurosci. 2002;3(6):453.

53. Kim JJ, Song EY, Kim JJ, Song EY, Kosten TA. Stress effects in the hippocampus:synaptic plasticity and memory. Stress. 2006:9(1):1-11.

54. Park HJ, Lee S, Jung JW, Kim BC, Ryu JH, Kim DH. Glucocorticoidand long-term stress-induced aberrant synaptic plasticity are mediated by activation of the glucocorticoid receptor. Arch Pharm Res. 2015;38(6):1204-12.

55. Wosiski-Kuhn M, Erion JR, Gomez-Sanchez EP, Gomez-Sanchez CE, Stranahan AM. Glucocorticoid receptor activation impairs hippocampa plasticity by suppressing BDNF expression in obese mice. Psychoneuroendocrinology. 2014;42:165-77.

56. Lupien, SJ, McEwen BS, Gunnar MR, Heim C. Effects of stress throughout the lifespan on the brain, behavior and cognition. Nature Rev Neurosci. 2009;10(6):434-45.

57. Green KN, Billings LM, Roozendaal B, McGaugh J, LaFerla FM. Glucocorticoids increase amyloid- $\beta$ and tau pathology in a mouse model of Alzheimer's disease. Neurobiol Dis. 2006;26(35):9047-56.

58. Kulstad JJ, McMillan PJ, Leverenz JB, Cook DG, Green PS, Peskind ER, et al. Effects of chronic glucocorticoidadministration on insulin-degrading enzyme and amyloid- $\beta$ peptide in the aged macaque. J. Neuropathol. Exp Neurol. 2005;64(2):139-46.
59. Sotiropoulos I, Catania C, Pinto LG, Silva R, Pollerberg GE, Takashima A, et al. Stress acts cumulatively to precipitate Alzheimer's disease-like tau pathology and cognitive deficits. J Neurosci. 2011;31(21):7840-7.

60. Catania C, Sotiropoulos I, Silva R, Onofri C, Breen KC, Sousa N, et al. The amyloidogenic potential and behavioral correlates of stress. Mol psych. 2009;14(1):95

61. Dong H, Yuede CM, Yoo HS, Martin MV, Deal C, Mace AG, et al. Corticosterone and related receptor expression are associated with increased $\beta$-amyloid plaques in isolated Tg2576 mice. Neuroscience. 2008;155(1):154-63.

62. Baglietto-Vargas D, Medeiros R, Martinez-Coria H, LaFerla FM, Green $\mathrm{KN}$. Mifepristone alters amyloid precursor protein processing to preclude amyloid beta and also reduces tau pathology. Biol psych. 2013; 74(5):357-66.

63. Peavy GM, Santiago DP, Edland SD. Subjective memory complaints are associated with diurnal measures of salivary cortisol in cognitively intact older adults. Am J Geriatr Psychiatry. 2013;21(9):925-8.

64. Lupien S, Lecours AR, Lussier I, Schwartz G, Nair NP, Meaney MJ. Basal cortisol levels and cognitive deficits in human aging. J Neurosci. 1994;14(5, Pt. 1):2893-903

65. Andel R, Crowe M, Kåreholt I, Wastesson J, Parker MG. Indicators of job strain at midlife and cognitive functioning in advanced old age. J Gerontol B Psychol Sci Soc Sci. 2011;66(3):287-91.

66. Andel R, Infurna FJ, Hahn Rickenbach EA, Crowe M, Marchiondo L, Fisher GG. Job strain and trajectories of change in episodic memory before and after retirement. J Epidemiol Community Health. 2015;69(5): 442-6.

67. Fiocco AJ, Wan N, Weekes N, Pim H, Lupien SJ. Diurnal cycle of salivary cortisol in older adult men and women with subjective complaints of memory deficits and or depressive symptoms:Relation to cognitive functioning. Stress. 2006:9(3):143-52.

68. Sindi S, Hagman G, Håkansson K, Kulmala J, Nilsen C, Kåreholt I, Soininen $\mathrm{H}$, Solomon A, Kivipelto M. Midlife Work-Related Stress Increases Dementia Risk in Later Life:The CAIDE 30-Year Study. J Gerontol B Psychol Sci Soc Sci. 2016;72(6):1044-53.

69. Davis KL, Davis BM, Greenwald BS, Mohs RC, Mathe AA, Johns CA, et al. Cortisol and Alzheimer's disease, I:Basal studies. Am J Psychiatry. 1986:143:300-05

70. Maeda K, Tanimoto K, Terada T, Shintani T, Kakigi T. Elevated urinary free cortisol in patients with dementia. Neurobiol Aging. 1991:12(2):161-3.

71. O'Brien JT, Ames D, Schweitzer I, Colman P, Desmond P, Tress B. Clinical and magnetic resonance imaging correlates of hypothalamicpituitary-adrenal axis function in depression and Alzheimer's disease. Br J Psychiatry. 1996;168(6):679-87.

72. Hartmann A, Veldhuis JD, Deuschle M, Standhardt H, Heuser I. Twentyfour-hour cortisol release profiles in patients with Alzheimer's and Parkinson's disease compared to normal controls:ultradian secretory pulsatility and diurnal variation. Neurobiol Aging. 1997;18(3):285-9.

73. Swanwick GR, Kirby M, Bruce I, Buggy F, Coen RF, Coakley D, et al. BA. Hypothalamic-pituitary-adrenal axis dysfunction in Alzheimer's disease:lack of association between longitudinal and cross-sectional findings. Am J Psychiatry. 1988;155(2):286-9.

74. Umegaki $\mathrm{H}$, Ikari $\mathrm{H}$, Nakahata $\mathrm{H}$, Endo $\mathrm{H}$, Suzuki $\mathrm{Y}$, Ogawa $\mathrm{O}$, et al. Plasma cortisol levels in elderly female subjects with Alzheimer's disease:a crosssectional and longitudinal study. Brain Res. 2000;881(2): $241-3$

75. Lind K, Edman A, Nordlund A, Olsson T, Wallin A. Increased saliva cortisol awakening response in patients with mild cognitive impairment. Dement Geriatr Cogn Dis. 2007;24(5):389-95.

76. Popp J, Schaper K, Kolsch H, Cvetanovska G, Rommel F, Klingmüller D, et al. CSF cortisol in Alzheimer's disease and mild cognitive impairment. Neurobiol Aging. 2007;21(3):1-3.

77. Csernansky JG, Dong H, Fagan AM, Wang L, Chengjie X, Holtzman DM, et al. Plasma Cortisol and Progression of Dementia in Subjects with Alzheimer-Type Dementia. Am J Psychiatry;2006;163(12):2164-9.

78. Souza-Talarico JN, Chaves EC, Lupien SJ, Nitrini R, Caramelli P. Relationship between cortisol levels and memory performance may be modulated by the presence or absence of cognitive impairment:evidence from healthy elderly, mild cognitive impairment and Alzheimer's disease subjects. J Alzheimers Dis. 2010;19(3):839-48.

79. Popp J, Wolfsgruber S, Heuser I, Peters O, Hüll M, Schröder J, et al Cerebrospinal fluid cortisol and clinical disease progression in $\mathrm{MCl}$ and dementia of Alzheimer's type. Neurobiol Aging. 2015;36(2):601-7.

80. Gasparini L, Netzer WJ, Greengard P, Xu H. Does insulin dysfunc- 
tion play a role in Alzheimer's disease? Trends in Pharmacol Sci. 2002;23(6):288-3.

81. Salkovic-Petrisic M, Hoyer S. Central insulin resistance as a trigger for sporadic Alzheimer-like pathology:an experimental approach. J Neural Transm. 2007;72:217-33.

82. Correia SC, Santos RX, Perry G, Zhu X, Moreira PL, Smith MA. Insulinresistant brain state:The culprit in sporadic Alzheimer's disease? Aging Res Rev. 2011;10(2):264-73.

83. Correia SC, Santos RX, Carvalho C, Cardoso S, Candeia E, Santos MS et al. Insulin signaling, glucose metabolism and mitochondria: Majorplayers in Alzheimer's disease and diabetes interrelation. Brain Res. 2012;1441:64-78.

84. Santos TO, Mazucanti CHY, Xavier GF, Torrão AS. Early and late neurodegeneration and memory disruption after intracerebroventricular streptozotocin. Physiol Behav. 2012;107(3):401-13.

85. de la Monte SM, Wands JR. Review of insulin and insulin-like growth factor expression, signaling, and malfunction in the central nervous system: relevance to Alzheimer's disease. J Alzheimers Dis. 2005;7(1): 45-61.

86. Lu FP, Lin KP, Kuo HK. Diabetes and the risk of multi-system aging phenotypes:a systematic review and meta-analysis. PloS one. 2009;4(1): e4144.

87. Notarianni, E. Cortisol. Mediator of association between Alzheimer's disease and diabetes mellitus?. Psychoneuroendocrinology. 2017;81: 129-37.

88. Ledochowski M, Murr C, Jäger M, Fuchs D. Dehydroepiandrosterone, ageing and immune activation. Exp Gerontol. 2001;36(10):1739-47.

89. Bastianetto S, Ramassamy C, Poirier J, Quirion R. Dehydroepiandrosterone (DHEA) protects hippocampal cells from oxidative stress-induced damage. Mol Brain Res. 1999;66(1):35-41.

90. Khalil A, Lehoux JG, Wagner RJ, Lesur O, Cruz S, Dupont É, et al. Dehydroepiandrosterone protects low density lipoproteins against peroxida-

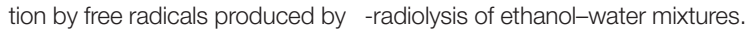
Atherosclerosis. 1998;136(1):99-107.

91. Aldred S, Mecocci P. Decreased dehydroepiandrosterone (DHEA) and dehydroepiandrosterone sulfate (DHEAS) concentrations in plasma of Alzheimer's disease (AD) patients. Arch Gerontol Geriatr. 2010;51(1): e16-e18.

92. Genedani S, Rasio G, Cortelli P, Antonelli F, Guidolin D, Galantucci M, et al. Studies on homocysteine and dehydroepiandrosterone sulphate plasma levels in Alzheimer's disease patients and in Parkinson's disease patients. Neurotox Res. 2004;6(4):327-32.

93. Cho SH, Jung BH, Lee WY, Chung BC. Rapid column囚switching liquid chromatography/mass spectrometric assay for DHEA囚sulfate in the plasma of patients with Alzheimer's disease. Biomed Chromatogr. 2006;20(10):1093-7.

94. Cardounel A, Regelson W, Kalimi M. Dehydroepiandrosterone Protects Hippocampal Neurons Against Neurotoxin-Induced Cell Death: Mechanism of Action 2 (44437). Proc Soc Exp Biol Med. 1999;222(2):145-9.

95. Cojocaru IM, Cojocaru M, Miu GA, Sapira V. Study of interleukin-6 production in Alzheimer's disease. Rom J Intern Med. 2011;49(1):55-8.

96. Eikelenboom P, Veerhuis R, Scheper W, Rozemuller AJM, Van Gool WA, Hoozemans JJ. The significance of neuroinflammation in understanding Alzheimer's disease. J Neural Transm. 2006;113(11):1685.

97. Fogal B, Hewett SJ. Interleukin囚1 $\beta$ : a bridge between inflammation and excitotoxicity? J Neuroch. 2008;106(1):1-23.

98. Akiyama H, Barger S, Barnum S, Bradt B, Bauer J, Cole GM, et al. Inflammation and Alzheimer's disease. Neurobiol Aging. 2000;21(3): 383-421.

99. Lai KSP, Liu CS, Rau A, Lanctôt KL, Köhler CA, Pakosh M, et al. Peripheral inflammatory markers in Alzheimer's disease:a systematic review and meta-analysis of 175 studies. J Neurol Neurosurg Psychiatry. 2017; 88(10):876-82.

100. Grimaldi LME, Zappalà G, lemolo F, Castellano AE, Ruggieri S, Bruno G, et al. A pilot study on the use of interferon beta-1a in early Alzheimer's disease subjects. J Neuroinfl. 2014;11(1):30.

101. Atzmon G, Gabriely I, Greiner W, Davidson D, Schechter C, Barzilai N. Plasma HDL levels highly correlate with cognitive function in exceptional longevity. J Gerontol Biol Sci Med Sci. 2002;57(11):M712-5.

102. Hottman DA, Chernick D, Cheng S, Wang Z, Li L. HDL and cognition in neurodegenerative disorders. Neurobiol Dis. 2014;72:22-36.

103. Van Exel E, de Craen AJ, Gussekloo J, Houx P, Bootsma区van der Wiel A Macfarlane PW, et al. Association between high囚density lipoprotein and cognitive impairment in the oldest old. Annals Neurol. 2002;51(6):716-21.

104. Singh-Manoux A, Gimeno D, Kivimaki M, Brunner E, Marmot MG. Low
HDL cholesterol is a risk factor for deficit and decline in memory in midlife. Arterioscler, thromb vasc biol. 2008;28(8):1556-62.

105. van den Kommer TN, Dik MG, Comijs HC, Jonker C, Deeg DJ. The role of lipoproteins and inflammation in cognitive decline:Do they interact?. Neurobiol Aging. 2012;33(1):196-e1.

106. Reiss AB, Siller KA, Rahman MM, Chan ES, Ghiso J, de Leon MJ. Cholesterol in neurologic disorders of the elderly:stroke and Alzheimer's disease. Neurobiol Aging. 2004;25(8):977-89.

107. Libby P, Ridker PM. Novel inflammatory markers of coronary risk. Circulation. 1999;100(11):1148-50

108. Sacco RL, Benson RT, Kargman DE, Boden-Albala B, Tuck C, Lin IF, et al. High-density lipoprotein cholesterol and ischemic stroke in the elderly: the Northern Manhattan Stroke Study. JAMA, 2001;285(21):2729-35.

109. Cockerill GW, Huehns TY, Weerasinghe A, Stocker C, Lerch PG, Miller $\mathrm{NE}$, et al. Elevation of plasma high-density lipoprotein concentration reduces interleukin-1-induced expression of E-selectin in an in vivo model of acute inflammation. Circulation. 2001;103(1):108-12.

110. Song F, Poljak A, Crawford J, Kochan NA, Wen W, Cameron B, et al. Plasma apolipoprotein levels are associated with cognitive status and decline in a community cohort of older individuals. PloS One. 2012; 7(6):e34078.

111. Merched A, Xia Y, Visvikis S, Serot JM, Siest G. Decreased high-density lipoprotein cholesterol and serum apolipoprotein Al concentrations are highly correlated with the severity of Alzheimer's disease区. Neurobiol Aging. 2000;21(1):27-30.

112. Reitz C, Tang MX, Schupf N, Manly JJ, Mayeux R, Luchsinger JA. Association of higher levels of high-density lipoprotein cholesterol in elderly individuals and lower risk of late-onset Alzheimer disease. Arch Neurol. 2010;67(12):1491-7.

113. Bonarek M, Barberger-Gateau P, Letenneur L, Deschamps V, Iron A, Dubroca B, et al. Relationships between cholesterol, apolipoprotein $\mathrm{E}$ polymorphism and dementia:a cross-sectional analysis from the PAQUID study. Neuroepidemiology. 2000;19(3):141-8.

114. Barnes DE, Yaffe K. The projected effect of risk factor reduction on Alzheimer's disease prevalence. Lancet Neurol. 2011;10(9):819-28.

115. Profenno LA, Porsteinsson AP, Faraone SV. Meta-analysis of Alzheimer's disease risk with obesity, diabetes, and related disorders. Biol Psychiatry. 2010;67(6):505-12.

116. Beydoun MA, Beydoun HA, Wang Y. Obesity and central obesity as risk factors for incident dementia and its subtypes:a systematic review and meta冈analysis. Obes Rev. 2008;9(3):204-18.

117. Koyama A, O'Brien J, Weuve J, Blacker D, Metti AL, Yaffe K. The role of peripheral inflammatory markers in dementia and Alzheimer's disease:a meta-analysis. J Gerontol Biom Sci Med Sci. 2012;68(4):433-40.

118. Seeman TE, McEwen BS, Rowe JW, Singer, BH. Allostatic load as a marker of cumulative biological risk:MacArthur studies of successful aging. Proc Nat Acad Sci. 2001;98(8):4770-5

119. Karlamangla AS, Miller-Martinez D, Lachman ME, Tun PA, Koretz BK, Seeman TE. Biological correlates of adult cognition:Midlife in the United States (MIDUS). Neurobiol Aging. 2014;35(2):387-94.

120. Booth T, Royle NA, Corley J, Gow AJ, Hernández MDCV, Maniega SM, et al. Association of allostatic load with brain structure and cognitive ability in later life. Neurobiol Aging. 2015;36(3):1390-9.

121. Goldman N, Turra CM, Glei DA, Seplaki CL, Lin YH, Weinstein M. Predicting mortality from clinical and nonclinical biomarkers. J Gerontol Biol Sci Med Sci. 2006;61(10):1070-4

122. Karlamangla AS, Singer BH, Seeman TE. Reduction in allostatic load in older adults is associated with lower all-cause mortality risk:MacArthur studies of successful aging. Psychosom Med. 2006;68(3):500-7.

123. Davis SR, Shah S, McKenzie D, Kulkarni J, Davison S, Bell R. Dehydroepiandrosterone Sulfate Levels Are Associated with More Favorable Cognitive Function in Women. Clin Endocrinol Metabol 2008;93(3):801-8.

124. Takeda JRT, Matos TM, Souza-Talarico JN. Cardiovascular risk factors and cognitive performance in aging. Dement Neuropsychol, 2017;11: 442-48.

125. Hassing LB, Dahl AK, Pedersen NL, Johansson B. Overweight in midlife is related to lower cognitive function 30 years later:A prospective study with longitudinal assessments. Dement Geriatr Cogn Disord. 2010;29:543-52.

126. Harvey J, Solovyova N, Irving A. Leptin and its role in hippocampal synaptic plasticity. Prog Lipid Res. 2006;45:369-78.

127. Perez-Gonzalez R, Antequera D, Vargas T, Spuch C, Bolos M, Carro E. Leptin induces proliferation of neuronal progenitors and neuroprotection in a mouse model of alzheimer's disease. J Alzheimers Dis. 2011;24(Suppl 2):17-25 
128. Niedowicz DN, Studzinski CM, Weidner AM, Platt TL, Kingry KN, Beckett TL, Bruce-Keller AJ, Keller JN, Murphy MP. Leptin Regulates Amyloid $\beta$ Production Via the $\bowtie$-Secretase Complex. Biochim Biophys Acta. 2013;1832(3):439-44.

129. Lieb W, Beiser AS, Vasan RS, Tan ZS, Au R, Harris TB, et al. Association of plasma leptin levels with incident alzheimer disease and mri measures of brain aging. JAMA. 2009;302:2565-72.

130. Power DA, Noel J, Collins R, O'Neill D. Circulating leptin levels and weight loss in alzheimer's disease patients. Dement Geriatr Cogn Disord. 2001;12:167-70.

131. Holden KF, Lindquist $K$, Tylavsky FA, Rosano C, Harris TB, Yaffe $K$. Serum leptin level and cognition in the elderly:Findings from the health abc study. Neurobiol Aging. 2009;30:1483-9.

132. Benson S, Arck PC, Tan S, Mann K, Hahn S, Janssen OE, et al. Effects of obesity on neuroendocrine, cardiovascular, and immune cell responses to acute psychosocial stress in premenopausal women. Psychoneuroendocrinology. 2009;34:181-9.
133. Watanabe Y, Kitamura K, Nakamura K, Sanpei K, Wakasugi M, Yokosek A, et al. Elevated C-Reactive Protein Is Associated with Cognitive Decline in Outpatients of a General Hospital:The Project in Sado for Total Health (PROST). Dement Geriatr Cogn Dis Extra. 2016;6(1):10-9.

134. Noble JM, Manly JJ, Schupf N, Tang MX, Mayeux R, Luchsinger JA. Association of C-Reactive Protein With Cognitive Impairment. Arch Neurol. 2010;67(1):87-92

135. Otaegui-Arrazola A, Amiano P, Elbusto A, Urdaneta E, Martinez-Lage P. Diet, cognition, and Alzheimer's disease:food for thought. Eur J Nutr. 2014;53:1-23

136. Santos JR, Gois AM, Mendonça DM, Freire MAM. Nutritional status, oxidative stress and dementia:the role of selenium in Alzheimer's disease. Front Aging Neurosci. 2014;6:206.

137. Spaccavento S, DelPrete M, Craca A, Fiore P. Influence of nutritional status on cognitive, functional and neuropsychiatric deficits in Alzheimer's disease. Arch Gerontol Geriatr 2009:48:356-60. 